\title{
The Ontario Medical Library Association 1887-1907
}

\author{
David S. Crawford
}

\begin{abstract}
In the 19th century it was difficult for the growing number of medical practitioners in North America to access current medical literature. Various ways were suggested to solve this problem; one of them was the creation of physician-run medical library associations. After other failed attempts, Ontario physicians formed the Ontario Medical Library Association (OMLA) in 1887. In 1907 the OMLA became the nucleus of the Academy of Medicine, Toronto.
\end{abstract}

In the mid- to late-19th century, the medical profession in North America was growing both in numbers and importance, generating strong support for better (or at least some) access to current medical literature so that practitioners could keep abreast of the many recent developments. In the United States, following the Civil War, the Library of the Surgeon-General's Office (established in 1835) was being reorganized and revitalized by John Shaw Billings, who was its director from 1865 to 1895 . Under his leadership, the first volume of the Index Medicus was published in 1879, and the first volume of the Index Catalogue was published in 1880 [1].

Until the middle of the 19th century, most "medical libraries" were private collections. There were certainly a few medical societies and medical schools with small book and journal collections, but there were few libraries in the modern sense of the word. The libraries that did exist tended to be storehouses of older material. In Canada, McGill University's Faculty of Medicine Library, the oldest medical library in Canada, was founded in 1823 by the staff of the Montreal General Hospital. "The first Library was situated in the Montreal Medical Institution ... [and] contained a couple of hundred books and periodicals" [2]. By the mid-19th century there was a growing (though not universally supported) movement in the United States to establish public medical collections within the civic public libraries that were then beginning to be developed [3]. The American Medical Association (AMA) was formed in 1847 and shortly thereafter established a Committee on Medical Literature. This group called for the establishment of public medical libraries in every major city, with a mandate to collect the current journals, transactions, and proceedings that were starting to be published in greater numbers. While the AMA committee was working towards distributed access to current material, the AMA itself was lobbying for an American Medical Re-

D.S. Crawford. Emeritus Librarian, McGill University.

Present address: 135 George Street South, No. 304, Toronto, ON

M5A 4E8, Canada (e-mail: david.crawford@mcgill.ca;

Web page: http://internatlibs.mcgill.ca/). pository "where the whole medical literature of this country and continent might be preserved" [4-7].

To provide access to current literature, local medical library associations were created by physicians in several cities. In addition to buying books and establishing their own libraries, many of the medical library associations created union catalogues, not the union catalogues of library holdings familiar to us, but catalogues of the books owned by member doctors. These catalogues were designed to allow practitioners to know which books were available from colleagues in their city or state.

One of the most vocal proponents of this solution was Charles David Spivak of Denver, Colorado [8]. Spivak had graduated in medicine from Jefferson Medical College in Philadelphia, Pennsylvania, in 1890, moved to Denver in 1891, and was one of the founders of the Colorado Medical Library Association in 1893. He was a strong supporter of the Association of Medical Librarians, which was to become the Medical Library Association in 1907. Having published several articles and columns on the subject of libraries and access to current medical literature in the Colorado Medical Journal, Spivak founded and edited the pioneering publication Medical Libraries from 1898 to 1902. This journal had as its goals the following:

First - To encourage founding of Medical Libraries and Medical Departments in Public Libraries, wherever the medical profession is fairly organized.

Second - To encourage the compilation of union catalogues of medical books and periodicals of private libraries.

Third - To further the project proposed by Dr. M. Gould of Philadelphia of organizing a Medical Librarians' Association and the perfecting of plans whereby the wasted medical literature all over the world may be utilized.

Fourth - To gather statistical data, publish reports, news and historical sketches of public and private medical libraries and biographies of medical librarians and book lovers [9].

In fact, while Spivak was organizing his colleagues in Denver, medical practitioners in many cities were taking 
things into their own hands. One of the earliest examples of a physician-run and physician-financed library is in Boston, Massachusetts, where the first Boston Medical Library was founded in 1805 [10]. It experienced the seemingly inevitable financial challenges faced by libraries, and after a shortlived merger into the Harvard medical library between 1816 and 1826, it combined its collection with that of the Boston Athenaeum: by 1843 , it had ceased to exist. Undaunted, in 1875 the Boston Medical Library was reborn, and at its first annual meeting in 1876, the Library decided to construct a new building, which opened in December 1878. Boston was not alone in its desire to create libraries of current medical material, and similar physician-run medical library associations sprang up all over North America. By the end of the 1890 s, there were medical library associations in several cities in the United States, including Utica (established in 1879), Denver (established in 1893), Cleveland (established in 1894), Toledo (established in 1896), and Wheeling (established in 1898). In Canada, a medical library association was founded in Toronto in 1887 [5].

The founding of these medical library associations reflected the growing professionalism of medicine. In the early 19 th century, in what is now Ontario, there was little or no control over who could practice medicine, but in 1815 , when there were estimated to be about 40 nonmilitary medical practitioners in the province, the provincial legislature established the Upper Canada Medical Board to licence physicians, surgeons, and midwives. The Board, appointed by the governor, consisted of "five or more persons legally authorized to practice physic, surgery or midwifery in this province ... [whose task was to] hear and examine all persons desirous to apply for a license, to practice physic, surgery or midwifery or either of them within this province". (Interestingly, the Act to Licence Practitioners in Physic and Surgery Throughout This Province also noted that "nothing in this Act shall extend to prevent any female from practicing midwifery in this province, or to require such a female to take out a license as aforesaid".) After a couple of years of inaction and a new act in 1818, the Board finally started to issue licences at its first meeting on 4 January 1819 [11,12].

Over the next decade the number of licensed medical practitioners grew, and following a public meeting held on 18 May 1833, the first medical society in Toronto, the Medico-Chirurgical Society of Upper Canada, was established in 1834, the same year that the City of Toronto itself was incorporated. The primary object of this Society was "the interchange and advancement of professional knowledge among the members of the profession" [11].

A few years later the Legislative Assembly of Upper Canada established a College of Physicians and Surgeons [13], primarily to replace the appointed Medical Board and to act as a licensing body. The College met for the first time on 13 May 1839, and at this meeting, in addition to issuing some licenses, it called on the Lieutenant-Governor to support the establishment of a medical school with "an ample library and museum". The College, of course, had no money to support this ambitious idea; at the same meeting they turned down the offer of "a box of books" from Dr. William Rees, ${ }^{1}$ because of a lack of funds.

In subsequent meetings the College continued to work on the establishment of a medical school, in conjunction with the University of King's College, and on 30 May 1839 they proposed that the university provide a grant of $£ 1000$ towards a library and museum. It is always easier to spend other people's money, but this was a considerable sum; at the same meeting they recommended that the proposed Professors of the School be paid $£ 200$ per year. The College clearly realized the value of a library and just as clearly recognized that libraries were expensive.

In August 1839, the College agreed to rent premises suitable for a meeting room and library. At the same meeting they agreed to subscribe to "the journal edited by Dr. Dunglison of Philadelphia" (presumably the American Medical Intelligencer, published 1837-1842; in January 1840 the College ordered the back issues) In October 1839, Black \& Armstrong, a firm of London booksellers, was asked to purchase the "Dublin medical journal" (presumably the Dublin Medical Press, which started publication in 1839) and to forward a catalogue of French medical books. Black \& Armstrong was also paid the sum of $£ 36$ and 13 shillings for books already received, and orders were placed for several more. At the College's first annual meeting in January 1840, it was proposed that a committee be established to set "rules" for the library. On 3 March 1840, it was reported that a box of books and journals sent by Black \& Armstrong had been damaged by water on the voyage from London, but the College agreed to spend over $£ 6$ to rebind the material and to repurchase any missing issues. The officers of the College continued to keep a careful eye on the library, and on 4 May 1840 , authorized the payment of $£ 2$ and 10 shillings for a renewal of the subscription to the American Medical Intelligencer. Unfortunately, at the May 5 meeting, the College learned that the Governor-General had received notice that the Act to incorporate the College had been disallowed by the Imperial Government in London; it was claimed that the College infringed on the rights and privileges of the Royal College of Surgeons.

Though this was clearly a shock and a great disappointment, the College obviously thought it important to continue to support the library; at the same meeting they proceeded to approve the library rules:

Resolved: That until a suitable room for the Library can be obtained, the books of the College now in possession of the Secretary shall be allowed to circulate among the Fellows of the College under certain conditions:

Restriction No. 1. Every Fellow receiving a book from the Steward of the Hospital shall deposit with him as a pledge for its safety and return within fourteen days the sum of "two dollars".

Restriction No. 2. Every book shall be returned when done with, to the Steward, and not transferred from Fellow to Fellow.

\footnotetext{
${ }^{1}$ W. Canniff [11] quotes a correspondent who describes Rees (1800-1874) as "an Englishman ... but an eccentric. Through his energy the first lunatic asylum was established in Toronto [in 1841] and he was appointed to its superintendence and management thereof upon the principle, I assume, of 'putting a madman to watch a madman"”.
} 
Resolved: That at every quarterly meeting a committee of three be appointed to examine the state of the books.

Resolved: That the President, the Vice-President and R. Gwynne be the Committee for the current quarter.

Resolved: that the books of the College be for the present deposited in the Hospital, and that the key of the case be left with the Steward, who shall give the books to the Fellows, receive the deposit, and enter the name of the Fellows, between the hours of 12 and 1 o'clock, daily.

Resolved: That the Secretary be authorized to procure a case with shelves, lock and key, capable of containing all the books of the College.

Resolved: That the Secretary be authorized to procure Stencil Plates with the words "Coll Phys. and Surg. U.C." for the purpose of marking the books and plates.

Resolved: That a suitable book be procured for the library in which shall be entered the name of the person taking out any book, the title of the book and number of volume, with the dates of issuing and returning it, with any remarks which may be required as to the state it may be in when issued or returned [11].

Despite the protestations of the College, which was supported by the Governor, the authorities in London upheld the disallowance of the Act, and the College was dissolved in late 1840. At the final meeting on 5 January 1841, the following resolutions were passed:

Resolved: That the books and furniture of the Library of the College of Physicians and Surgeons be transferred to a committee of eight, who are Fellows of the College, in trust, for such purposes as the Fellows generally may deem the most expedient for the benefit of the profession and the continued existence of the library within this Province; and that such committee shall have power to fill up any vacancies which may occur by death or otherwise; and that such committee be composed of the following persons: C. Widmer, Esq., R.C. Horne, Esq., Dr. King, Dr. O'Brien, Dr. Shortt, Dr. Herrick, Henry Sullivan, Esq., and Dr. Boys.

Resolved: That the surplus funds remaining in the hands of the Treasurer be left in his hands, subject only to the control of the Committee, appointed by the last resolution, for the use of the library [11].

We do not know what happened for the next 3 years, but the Committee met in the autumn of 1844 :

At a meeting of the Fellows of the late College of Physicians and Surgeons of Upper Canada, held at the hospital, on the 15th day of October, 1844. (Present: C. Widmer, Dr. Herrick, Dr.Telfer, Dr. O'Brien and Dr. Boys.)

It was moved by Dr. Boys, and seconded by Dr. Telfer, the Medico-Chirurgical Society having applied to the Fellows of the late College of Physicians and Surgeons for the use of the Medical Books in their possession, it is resolved by the Fellows now present, that it will be proper to lend the books to that Society as soon as it shall appear that the Society have provided a fit place for their reception. And that the committee named at the meeting of 6th January, 1841, be now empowered to carry this resolution into effect [11].
After a few weeks of correspondence, four of the trustees (Widmer, O’Brien, Herrick, and Boys) met again:

Resolved: That the whole of the books constituting the library of the said College, together with the book-case, shall be delivered to the custody of Dr. Grassett, the Secretary of that said Medico-Chirurgical Society, a list of them being prepared, and a receipt given by Dr. Grassett.

Resolved: That this committee retains the power of reclaiming the possession of the said books and book-case at any time the Committee shall see fit [11].

Unfortunately, Dr. George Grassett, who was Chief Medical Officer of the Emigrant Hospital, died in the typhus epidemic of 1847, at the age of 36 [14]. The Medico-Chirurgical Society, in the words of Anderson [15], "dwindl[ed] out of existence" shortly afterwards. The College's books, and the bookcase, vanished.

In 1841, following the disbanding of the College, the government-appointed Medical Board was reconstituted, and for the next 25 years the medical profession in Toronto was quite factionalized and leaderless. Several medical schools appeared and disappeared, hospitals opened and closed, and the provision of books and libraries was not a high priority. Shortly after Canada's Confederation in 1867, the Canadian Medical Association was founded, and both medical education and the medical profession in Toronto became more unified. In 1878, after several decades with no organized medical societies existing or medical journals being published in the city, the Toronto Medical Society (TMS) was established. Shortly thereafter, in 1880, when there were approximately 2100 physicians in the province, the Ontario Medical Association (OMA) was founded as a voluntary association of the province's physicians. This action was led by the efforts of the TMS; the Hamilton Medical and Surgical Society (HMSS), which had been founded in 1863; and the College of Physicians and Surgeons of Ontario, which had been reestablished in 1869 [16,17].

On 28 April 1887, a committee was appointed by the TMS to work with other groups (in particular, the OMA and the HMSS) to investigate the creation of a combined medical library. The rather speedy result of this committee's work was the formation of a joint-stock company with capital of $\$ 10000$, in shares of $\$ 5$ each. This was the Ontario Medical Library Association, which held its first annual meeting on 13 July 1888. Annual membership fees were set at $\$ 2$ per year for residents of Toronto and $\$ 1$ for nonresidents. Owners of $\$ 100$ or more of stock were exempt from annual fees. As was normal at that time, a physician doubtless held the title of librarian, but an assistant librarian (Mary Scott Watson) was appointed. By 1889 the membership of the Association was reported to be 91 members, and the library included 1300 bound and 250 unbound items, with 59 journals on file. It is interesting to compare this with the McGill Medical Library, then one of the largest in North America, which had about 15000 volumes at that time [2].

Despite the fact that the College of Physicians and Surgeons provided accommodation for the library at a nominal rent, that both the TMS and the OMA provided annual grants, and that individual supporters contributed generously, the income of the new library was soon found to 
Fig. 1. Ontario Medical Library Association Board of Trustees card (reproduced with the permission of the Baldwin Room, Toronto Public Library).

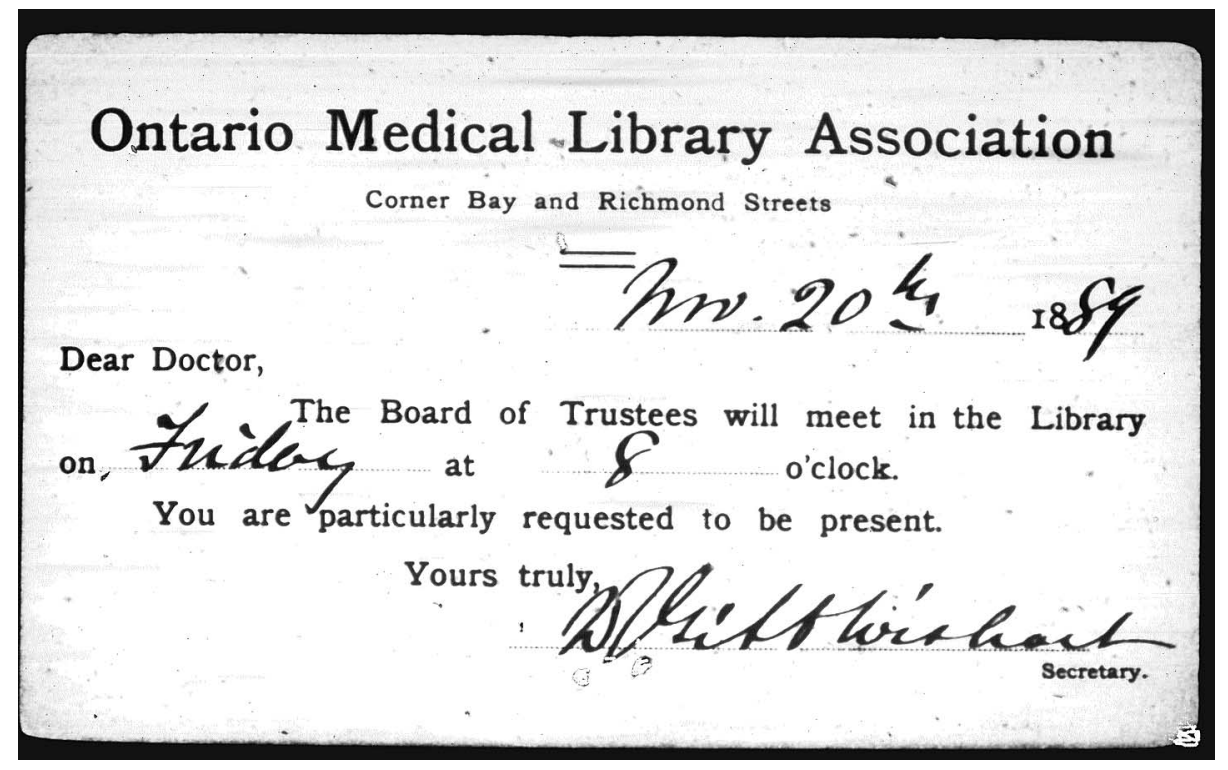

be insufficient. ${ }^{2}$ By 1902 memberships had dropped to 36, and the Ontario Medical Library Association was in such a financial mess that a special meeting was held on 10 March 1903. It was decided to increase the annual fee to $\$ 5$ and to launch an appeal both for new members and new funds. The appeal was quite successful. The membership increased, the Massey Foundation contributed \$5000, William Osler and his brother Sir Edmund (a banker and Member of Parliament) each contributed $\$ 500$, and the medical profession contributed \$3500. On 28 December 1904, William Osler returned to Canada and opened the new library building, which cost $\$ 10000[19,20]$.

The beginning of the 20th century was a time of further amalgamation in the medical community of Toronto. The medical schools in the city were further unified in the first few years of the new century, and this allowed for the reorganization of the hospital medical staffs. By 1900 Toronto had three medical societies: the Toronto Medical Society, founded in 1878; the Toronto Pathological Society, founded in 1889; and the Toronto Clinical Society, founded in 1892. In 1907, the same year that several medical societies united to become the Royal Society of Medicine in London [21], the three Toronto medical societies, all of whom already held meetings in the new library building, merged to form the Academy of Medicine. The Ontario Medical Library Association, which then had 117 members, held its final meeting on 4 June 1907 and voted to dissolve. In Anderson's words, "the library [which then had about 4600 volumes] became the nucleus of the new organization, designed to ensure its growth and stability, and the provincial aspect of the library was recognized by providing that medical practitioners throughout the province should have access to its facilities" [15].

The Academy of Medicine, Toronto thrived for many years. In addition to the library, the Academy offered meet- ing and dining rooms, arranged continuing education, and published a journal. The library grew in size and importance, holding a sizeable collection of both rare and current material. Margaret Charlton, one of the founders of the Medical Library Association and formerly the Assistant Librarian at the Medical Faculty Library of McGill University, was the Academy's librarian from 1914 to 1922 [22]. However, by the 1990s survival was increasingly difficult for medical clubs and libraries not affiliated with larger institutions, and in 1998 the Academy sold its building at Bloor Street and Avenue Road. The library was closed and its collection donated to the Toronto Hospital in June 1992. For a few years the Academy retained ownership, but on 5 July 1996, the collection became the property of the hospital (B. Trojan, personal communication, 2007). The hospital retained part of the collection, donated part of it to the University of Toronto and to other institutions, and the remainder was disposed of. The Academy now exists only virtually and offers occasional lectures.

\section{Acknowledgements}

Thanks to my colleagues and friends Deanna Cowan and Christopher Lyons at McGill University for their help, and to the Baldwin Room at the Toronto Public Library for permission to reproduce the Ontario Medical Library Association card.

\section{References}

1. Miles WD. A history of the National Library of Medicine, the nation's treasury of medical knowledge. Washington, D.C.: US Public Health Service, National Library of Medicine; 1982.

\footnotetext{
${ }^{2}$ In 1896 William Osler contributed $\$ 500$ to support the Bovell Collection, created in honour of his mentor, James Bovell. Osler also donated many books to the library, and in 1909, he and his brother Edmund presented the Academy with 58 medical engravings [18].
} 
2. Continuity \& change: 175 years of the McGill University Health Sciences Library. Montreal: McGill University Health Sciences Library; 1999.

3. Wannarka M. Medical collections in public libraries of the United States: a brief historical study. Bull Med Libr Assoc. 1968 Jan;56(1):1-14.

4. Spivak CD. Medical Libraries of the United States. Medical Libraries. 1899 Feb; 2(1 Suppl):1-14.

5. Connor J. Guardians of medical knowledge: the genesis of the Medical Library Association. Langham, Md.: Scarecrow Press; 2000.

6. Groen FK. Access to medical knowledge: libraries, digitization and the public good. Latham, Md.: Scarecrow Press; 2007.

7. Fishbein M. History of the American Medical Association 1847-1947. Philadelphia: Saunders; 1947.

8. Rogers FB. Welcoming address: "Colorado and the Medical Library Association 1898-1968”. Bull Med Libr Assoc. 1968 Oct;56(4):436-39.

9. Spivak CD. Our aim. Medical Libraries. 1898 Feb;1(1):1.

10. Boston Medical Library. A reconstruction of the collection of 1805 and its history [article on the Internet]. Boston: Countway Library of Medicine. Available from www. countway.harvard.edu/rarebooks/exhibits/BML_1805/bml_ 1805 . htm.

11. Canniff W. The medical profession in Upper Canada, 17831850. Toronto: Briggs; 1894. Reprinted by Clark Irwin in 1980 and digitized as part of Early Canadiana Online.

12. Province of Upper Canada. An Act to licence practitioners in physic and surgery throughout this Province. 1815. Chapter 10, 55th Year of George III. Subsequently amended by 1818 Chapter 13 of 58th Year of George III. Subsequently further amended by 1819 Chapter 2 of 59th Year of George III.

13. Province of Upper Canada. An Act to incorporate certain persons under the style and title of the College of Physicians and
Surgeons of Upper Canada. 1839. Chapter 38 of 2nd Year of Victoria.

14. Toronto Irish Famine Memorial [homepage on the Internet]. Toronto: Ireland Park Foundation; c2006. Available from www.irelandparkfoundation.com/index.php?p=2_1.

15. Anderson HB. History of the Library of the Academy of Medicine, Toronto. Bulletin of the Academy of Medicine, Toronto. 1938 Apr;11(7):142-53. Republished in Bulletin of the Academy of Medicine, Toronto. 1947 Aug;20(11):239-52.

16. Felleti P. Ontario Medical Association marks 125th anniversary [article on the Internet]. Ont Med Rev. 2005 June:33-5. Available from www.oma.org/pcomm/OMR/jun/ 05Commemorative.pdf.

17. Williams JA. The address of Dr. Williams, Retiring President of the Council of the College of Physicians and Surgeons of Ontario. Ontario Medical Journal.1892 Aug;1(1):1-10.

18. Gwyn NB. Sir William Osler's contributions to the library of the Academy of Medicine, Toronto. Bulletin of the Academy of Medicine, Toronto. 1938 Apr;11(7):154-58. Republished in Bulletin of the Academy of Medicine, Toronto. 1947 Sept;20(12):266-72.

19. Canada Lancet. 1905 Feb;38(6):539-40.

20. Opening of the new building of the Ontario Medical Library Association. Canada Practitioner and Review. 1905 Jan;30(1):39-41.

21. Godbolt S. The incomparable Mac: a biographical study of Sir John Young Walker MacAlister (1856-1925). London: Library Association; 1983.

22. Margaret Ridley Charlton [article on the Internet]. Montreal: Osler Library of the History of Medicine - McGill University; revised 2006 July. Available from www.health.library.mcgill.ca/ osler/charlton/index.htm. 
